\title{
Effect of Air Pollutants on Peak Expiratory Flow Rate of Public Bus Drivers in Bhaktapur, Nepal
}

\author{
Prabin Kumar Karki, ${ }^{1}$ Sushil Kharel, ${ }^{1}$ Gita Khakurel, ${ }^{1}$ Nripendra Tiwari ${ }^{2}$ \\ ${ }^{1}$ Department of Physiology, ${ }^{2}$ Department of Anatomy, Kathmandu Medical College and Teaching Hospital, Duwakot, \\ Kathmandu, Nepal.
}

\begin{abstract}
Background: Rapid increase in number of vehicles in Kathmandu valley over past decade and never ending road expansion projects has aggravated air pollution. People involved in transportation jobs for long duration like bus drivers, conductors are more vulnerable to ill effects of air pollutants. The purpose of the present study was to assess lung function of public bus drivers exposed to outdoor air pollution by means of PEFR. Methods: Fifty healthy, non smoking bus drivers were selected randomly from bus parks of Bhaktapur district. Anthropological records were taken. PEFR value was obtained by Mini Wright's peak flow meter. Their mean PEFR was compared with 50, age matched control group involved in other office works. Results: The PEFR value was significantly lower among bus drivers than the control group $(p<0.001)$. Mean PEFR decreased with increasing age and increased duration of bus driving. Conclusions: Our study concluded that PEFR value among bus drivers who are exposed to air pollutants for long period of time was significantly reduced.
\end{abstract}

Keywords: air pollution; bus drivers; PEFR.

\section{INTRODUCTION}

A good quality of air is an important factor for normal health of an individual. In 2016, WHO estimated $91 \%$ of the world population were breathing low quality air than the WHO guideline. It was predicted that 4.2 million premature deaths occurred worldwide in 2016 due to polluted air. Majority of those deaths occurred in low income countries including South East Asia. The burden of health hazards due to air pollution on developing countries continues to rise every year. ${ }^{1,2}$

Transportation is the backbone of development. But it has also become a major contributor of air pollution. People directly involved with transportation jobs for long hours like bus drivers, conductors are regularly inhaling injurious and poisonous substances from the vehicle emissions. Previous studies have shown that airway injuries can be caused by different contaminants of automobile fumes. ${ }^{3}$ Kathmandu valley is ranked as one of the most polluted city in the world. ${ }^{4}$ The primary sources of air pollution in Kathmandu valley are vehicles, poor road condition and industries. Due to mass increase in number of vehicles in Kathmandu valley over past decade, residents are exposed to several air pollutants from the automobile exhaust. ${ }^{5,6}$ These components have been proven as causative factors for different respiratory and cardiovascular pathology. ${ }^{7,8}$ Long term exposure to higher concentrations of automobile emissions like carbon monoxide, oxides of sulphur and nitrogen gas among transport workers are associated with irritation of lungs, bronchial asthma and chronic obstructive pulmonary diseases. $^{9}$

In a study done in Kathmandu and Lalitpur city to assess the air quality, more than $50 \%$ of the emissions were of particulate matter (PM10 and PM2.5). Carbon monoxide was found to be the second major air pollutant at $32 \%$ and other pollutants like sulphur dioxide, nitrogen oxides, nonmethane volatile organic compounds contributed to a total of $16 \%$. A staggering $69 \%$ of the total air pollution burden was contributed by transportation sector. ${ }^{10}$ Among the population exposed to these air pollutants, pulmonary function tests are used as regular screening tools to determine their effects. Among those, peak expiratory flow rate (PEFR) is one of the parameters that can be measured with ease. PEFR value is affected by various physiological factors like age, sex, height $\&$ weight. The peak expiratory flow rate (PEFR) is the maximal

Correspondence: Dr. Prabin Kumar Karki, Department of Physiology, Kathmandu Medical College and Teaching Hospital, Duwakot, Bhaktapur, Nepal. Email: prabinkaarki@gmail.com. Phone: +977-9841514299. DOI: 10.3126/ jcmsn.v15i1.20753.Article received: 2018-08-14. Article accepted: 2019-01-26. 
rate at which an individual can exhale by short maximum expiratory effort after a full inspiration. The simplicity by which peak flow rate can be measured with a cheaper and portable device has made it a useful tool of assessing different respiratory conditions. ${ }^{11}$ PEFR values taken immediately after waking up in the morning, before and after taking bronchodilator, before bed are helpful in determining airflow limitation in respiratory diseases. Determining diurnal variation in PEFR can help clinicians to measure asthma activity, its progression and treatment response. ${ }^{12}$ The purpose of the present study is to assess respiratory condition of public bus drivers exposed to outdoor air pollution by means of PEFR.

\section{METHODS}

A cross sectional study was conducted from March 2017 to December 2017. 50 male public bus drivers associated with different transport associations of Bhaktapur district (located inside Kathmandu valley) were included in the study. Age matched 50 male healthy subjects associated with different office works in Bhaktapur were randomly selected as control group. Persons with history of smoking from both the groups were excluded from the study.

Bus drivers with less than 6 months of experience, presence of any acute illness, history of lung diseases like chronic obstructive pulmonary disease or bronchial asthma were excluded from the study. The research proposal was approved by institutional review committee of Kathmandu Medical College and Teaching Hospital.

The subjects were informed that their participation is entirely voluntary. The procedure and purpose of the study were explained to them and written consent was taken. Pre-designed structured questionnaire was used for data collection. Questions related to education and socioeconomic status, total duration of driving in years were noted. Symptoms associated with any respiratory disease or history of previous respiratory illness and any medications taken were recorded. Height in centimeters and weight in kilograms were recorded.

Wright's peak expiratory flow meter was used for measuring ventilatory function. It is a small portable device with a mouth piece and a calibrated scale in litres per minute. Before the procedure proper instructions were given to the subjects for using Wright's peak expiratory flow meter. Subjects were asked to inspire maximally, then blow out as fast as they can into the mouthpiece of flow meter after nose clip was placed. The procedure was repeated 3 times at the interval of 2 minutes and the best recording was taken as the PEFR value. The PEFR readings were taken by only one researcher to avoid human error.

Data was collected, compiled and analyzed by using Statistical Package of Social Science (SPSS) software version 20 . The results were obtained as mean \pm SD. Students $t$ test was used for group comparisons. P-value of $<0.05$ was considered to be statistically significant.

\section{RESULTS}

100 subjects took part in this study (50 bus drivers and 50 age matched controls). The mean PEFR value among bus drivers was less than that of our control group, which was statistically significant (Table 1). The mean age of

\begin{tabular}{|lccc|}
\hline \multicolumn{3}{|c|}{$\begin{array}{l}\text { Table 1. Comparison of mean } \pm \text { SD of PEFR } \\
\text { among bus drivers and control group. }\end{array}$} & \\
\hline \multicolumn{1}{|c|}{ Subjects } & $\begin{array}{c}\text { PEFR Range } \\
\text { (litres/min) }\end{array}$ & $\begin{array}{c}\text { PEFR } \\
\text { Mean } \pm \text { SD } \\
\text { (litres/min) }\end{array}$ & $\begin{array}{c}\text { P } \\
\text { value }\end{array}$ \\
& & $424.06 \pm 59.16$ & \\
$\begin{array}{l}\text { Bus drivers } \\
\begin{array}{l}\text { Control } \\
\text { group }\end{array}\end{array}$ & $310-580$ & $471.24 \pm 66.73$ & $\mathrm{p}<0.05$ \\
\hline
\end{tabular}

participating bus drivers was $37.04 \pm 9.15$ years and control group was $35.90 \pm 8.25$ years (Table 2). There was no difference in other

Table 2. Comparison of age, height and weight of the subjects and the controls.

\begin{tabular}{|llll|}
\hline Parameter & Control group & Bus drivers & P Value \\
Age $($ years $)$ & $35.90 \pm 8.25$ & $37.04 \pm 9.15$ & NS \\
Height $(\mathrm{cm})$ & $163.30 \pm 3.79$ & $162.40 \pm 3.88$ & $\mathrm{p}>0.05$ \\
Weight $(\mathrm{kg})$ & $63.48 \pm 5.69$ & $66.14 \pm 6.00$ & $\mathrm{p}>0.05$ \\
\hline
\end{tabular}

physical parameters between these two groups. ( $>0.05)$. The result of our study showed that the mean PEFR value of both groups decreased with increasing age. There was statistically significant higher PEFR value among different age intervals in control group than bus drivers (Table 3).

\begin{tabular}{|c|c|c|c|c|c|}
\hline \multirow{2}{*}{$\begin{array}{l}\text { Age } \\
\text { group }\end{array}$} & \multicolumn{2}{|c|}{ Bus drivers } & \multicolumn{2}{|c|}{ Control } & \multirow[t]{2}{*}{ P value } \\
\hline & $\begin{array}{c}\text { Num- } \\
\text { ber of } \\
\text { sub- } \\
\text { jects }\end{array}$ & $\begin{array}{c}\text { PEFR } \\
\text { Mean } \pm \text { SD } \\
\text { (litres/ } \\
\text { min) }\end{array}$ & $\begin{array}{c}\text { Num- } \\
\text { ber of } \\
\text { sub- } \\
\text { jects }\end{array}$ & $\begin{array}{c}\text { PEFR } \\
\text { Mean } \pm \text { SD } \\
\text { (litres/ } \\
\text { min) }\end{array}$ & \\
\hline $\begin{array}{l}20-30 \\
\text { years }\end{array}$ & 17 & $\begin{array}{l}452.00 \pm 44 . \\
41\end{array}$ & 18 & $\begin{array}{l}517.52 \pm 63 \\
06\end{array}$ & $<0.001$ \\
\hline $\begin{array}{l}31-40 \\
\text { years }\end{array}$ & 20 & $\begin{array}{l}434.95 \pm 58 \\
66\end{array}$ & 19 & $\begin{array}{l}472.60 \pm 50 \\
06\end{array}$ & $<0.001$ \\
\hline $\begin{array}{l}>40 \\
\text { years }\end{array}$ & 13 & $\begin{array}{l}370.76 \pm 42 . \\
80\end{array}$ & 13 & $\begin{array}{l}408.61 \pm 40 . \\
35\end{array}$ & $<0.05$ \\
\hline
\end{tabular}


Karki et al. Effect of Air Pollutants on Peak Expiratory Flow Rate of Public Bus Drivers..

Our present study revealed that mean PEFR value among bus drivers decreased with an increase in duration of driving in years. Statistically highly significant differences were seen on comparing PEFR values of different groups (Table 4).

\begin{tabular}{|lcc|}
\hline $\begin{array}{l}\text { Table 4. PEFR in } \\
\text { among bus drivers. }\end{array}$ & relation to duration of driving \\
\hline Duration of driving & $\begin{array}{c}\text { Number of } \\
\text { subjects }\end{array}$ & $\begin{array}{c}\text { PEFR Mean } \pm \text { SD } \\
\text { (litres/min) }\end{array}$ \\
$<10$ years ( Group A) & 19 & $461.05 \pm 51.89$ \\
$10-20$ years (Group B) & 19 & $420.26 \pm 48.21$ \\
$>20$ years (Group C) & 12 & $371.50 \pm 44.62$ \\
Group A vs Group B & & $\mathrm{p}<0.05$ \\
Group A vs Group C & & $\mathrm{p}<0.05$ \\
Group B vs Group C & & $\mathrm{p}<0.05$ \\
\hline
\end{tabular}

\section{DISCUSSION}

Long hours of exposure to pollutants in air have adverse effects on respiratory system of public vehicle drivers. PEFR is helpful in determining the extent of respiratory insufficiency. The present research was done to evaluate the effect of air pollutants on public bus drivers by measuring their PEFR values and comparing with control subjects.

PEFR value was lower among bus drivers than the control group. The difference was highly significant statistically $(p<0.001)$. This result was in accordance with previous studies done by Binawara BK et al, ${ }^{13}$ and other researchers in South Asia. ${ }^{3,14-16}$ Till date no such data was found related to Nepalese vehicle drivers. However, Shrestha HS et al, ${ }^{17}$ found significant decrease in pulmonary function test parameters among traffic police of Kathmandu valley than the controls.

We could not find significant difference in anthropological parameters like age, height and weight between our study group and controls. This result indicated that physical parameters were not the factor for difference of PEFR between two study groups.

Results in our study showed that mean PEFR value in all the participants decreased with an increasing age. Study participants were divided in to three groups according to age. Mean PEFR of bus drivers were significantly lower than that of controls in each age group. These results were similar with studies done by Jain et al. ${ }^{14}$ According to the duration of years they were involved in driving, bus drivers were divided in to three groups. 19 of them were working for less than 10 years, 19 subjects were involved between 10 to 20 years of service and remaining 12 were driving for more than 20 years. The results showed mean PEFR among the bus drivers decreased with increase in duration of their driving years, which was statistically significant. Jain A et al, ${ }^{14}$ found similar results in a study done in Patiala, Punjab, 2011 and other researchers reported the same kind of result. ${ }^{16}$

The reduced PEFR value among bus drivers in this study is probably due to prolonged exposure to air pollutants that caused ill effects on their respiratory system. The effects were more pronounced with increased age and duration of their bus driving occupation. However, we cannot neglect the contribution of air pollutants from brick kilns during winter in Bhaktapur district, highlighting the need for further large scale studies.

To minimize the hazards of polluted air strong policies should be made and implemented from state as well as national government. Rules like displacing old and ill maintained vehicles from Kathmandu valley should be strictly followed. Encouraging people to use mass transportation instead of personal vehicle, heavy tax reduction in electric vehicles, proper and timely maintenance of roads are few things that will help reduce the automobile air pollution.

\section{CONCLUSIONS}

There is no doubt that people involved in automobile occupation are exposed to air pollutants for long period of time. This affects their respiratory as well as functions of other system. This study showed that bus drivers have significant reduction in mean PEFR than the control group. The bus drivers should be given education about ill effects of air pollution, should be encouraged to use protective masks and make habit of regular health check up

\section{ACKNOWLEDGEMENTS}

We sincerely thank all the study participants who were involved in the study.

\section{REFERENCES}

1. Ambient (outdoor) air quality and health. [Internet]. WHO. 2nd May 2018 [cited 2018 June 10] .Available from:http://www.who.int/news-room/ fact-sheets/detail/ambient-(outdoor)-air-quality-andhealth.

2. HEI. International scientific oversight committee outdoor air pollution and health in the developing countries of asia: A Comprehensive Review. Special Report 18. Boston, MA ;2010.

3. Pramanik P, Ganguli IN, Chowdhury A, Ghosh B. A study to assess the respiratory impairments 
Karki et al. Effect of Air Pollutants on Peak Expiratory Flow Rate of Public Bus Drivers..

among three wheeler auto taxi drivers. Int. J. Life Sci Pharma Res.2013;3(1)94-9.

4. Kumari O, Regmi PR, Pant RR. Implication of air pollution on health effects in Nepal: lessons from global research. Nepal J Epidemiol. 2016;6(1):52527.

5. Joshi SK. Air pollution in Nepal. KUMJ. 2003;1 (4):232.

6. Gautam DR. Air pollution : Its causes and consequences with reference to Kathmandu metropolotian city. The third pole. 2010;8-10:2733.

7. Del Donno M, Verduri A, Olivieri D. Air pollution and reversible chronic respiratory diseases. Monaldi Arch Chest Dis. 2002;57(3-4):164-66.

8. Uzoigwe JC, Prum T, Bresnahan E, Garelnabi M. The Emerging Role of Outdoor and Indoor Air Pollution in Cardiovascular Disease. North Am J Med Sci. 2013;5(8):445-53.

9. Balashanmugam P, Ramanathan AR, Nehrukumar V. Ambient Air Quality Monitoring in Puducherry. Int J Eng Res Appl. 2012;2(2):300-07.

10. Pradhan BB, Dangol PM, Bhaunju RM, Pradhan S (2012). Rapid urban assessment of air quality for Kathmandu , Nepal: Summary. Kathmandu: ICIMOD.

11. Eid N, Yandell B, Howell L, Eddy M, Sheikh S. Can peak expiratory flow predict airflow obstruction in children with asthma? Pediatrics. 2000 Feb; 105(2):354-8.

12. UK Essays. Peak Expiratory Flow rate (PEFR) in Lung Diseases [Internet]. November 2013. [Accessed 20 September 2018]; Available from: https:/www.ukessays.com/essays/biology/value-of -pefr-measurement-in-lung-diseases-biologyessay.php?vref $=1$.

13. Binawara BK, Gahlot S, Mathur KC, Kakwar A, Gupta R, Rajnee. Pulmonary function tests in three wheeler diesel taxi drivers in Bikaner city. Pak J Physiol. 2010;6(1):28-31.

14. Jain A, Singh M. Effect of occupational exposure to pollutants on peak expiratory flow rate of healthy non-smoking bus drivers in the age group of 20-55 years. JCDR 2012 April;6(2):176-79.

15. Farooque I, Jayachandra S. Pulmonary function tests in nonsmoking auto rickshaw drivers. Al Ameen J Med Sci. 2014;7(3):240-43.

16. Ajay KT, Vatsala AR, Prabhuraj, Sangam. Comparative study of PEFR between Auto drivers with the residents of urban Davangere. J. Pharm. Sci. \& Res. 2014;6(5):226-28.

17. Shrestha HS, Nepal O, Khanal K, Kapoor BK.. A cross-sectional study of lung functions in traffic police personnel at work in Kathmandu Valley, Nepal. ACCLM. 2015;1(1):42-48.

Citation: Karki PK, Kharel S, Khakurel G, Tiwari N. Effect of Air Pollutants on Peak Expiratory Flow Rate of Public Bus Drivers in Bhaktapur, Nepal. JCMS Nepal. 2019;15(1):30-3. 